Проф. д-р Мариа Доневска

Универзитет „Св. Кирил и Методиј“- Скопје, Филозофски факултет

Институт за социјална работа и социјална политика „Мајка Тереза“

\title{
Континуитет и промени во социјалната работа (македонски контекст)
}

UDK: 364-78-1(497.7)

Феноменот социјална работа, кој привлекува кон своите хумани активности многубројни групи на волонтери од невладиниот сектор, активисти на хуманитарни организации, локални лидери, мисионери на сите верски заедници, а пред сѐ професионално подготвени лица, е придружен елемент на човековото битие. Сепак, од аспект на професија, можеме да зборуваме за неа од 1900 година кога Мери Ричмонд го вовела поимот социјален работник. Во сите години кои поминале од тој настан се случувало многу, но од нив најкарактеристична била, и сѐ уште постои, борбата за научна самостојност на социјалната работа, настојувањата за државното признавање како професија, развој на посебен методски опус, социјалното управување, етичката компатибилност и соодветното образование.

Се поставува прашањето што не е променето, а што е ново во социјалната работа од аспект на нејзините теоретски и практични димензии и како развојот на дејноста се одразува врз состојбите на социјалната работа во Македонија. ${ }^{1}$

\footnotetext{
${ }^{1}$ Во трудот поимот социјален работник се однесува на сите профили вработени во социјалните институции, што е практика во многу земји.
} 
Ревија за соиијална политика, год. 8, бр.11/2 Скопје, ноември 2015

\section{1. Борба за научна самостојност}

Првата книга која се смета за научна во социјалната работа, под наслов „Социјална дијагноза“, била објавена во 1917 година, што значи скоро пред 100 години. Иако од тоа време стручната и научната литература се збогатени за многу наслови, кај одредена група на научници постои недоверлив став кон теоријата на социјалната работа како научна дисциплина.

Се согласуваме дека социјалната работа има интердисциплинарен карактер, бидејќи ги користи теоретските, методолошките и дијагностичките придонеси од другите науки, но сепак располага со свои дефиниции и тврдења, описни реченици и судови со аксиолошка компонента, како и практични упатства.

Како што произлегува од методолошките анализи, најкохерентна теорија за социјалната работа е еколошко-системската перспектива. Во нејзиниот контекст екологијата и системите се поврзани преку набљудување на единката како феномен составен од различни потсистеми (физички, социјален, сексуален, духовен).

Сепак, особено социјалните педагози и социолози, сметат дека социјалната работа е нивна субдисциплина или функција. Краковскиот социолог К. Фриштацки (Frysztacкi, K., 2002:17 ) ја третира социјалната работа како практична социологија, додека социјалните педагози ја сметаат за своја функција.

Врската помеѓу социјалната работа и социјалната педагогија е неизбежна поради средината како поле на нивно проучување. Кога социјалната педагогија ги анализира влијанијата од страна на средината, средбата со социјалната работа е неминовна.

За социјалната работа потребна е теоретската инспирација на социјалната педагогија, додека социјалната педагогија црпи од социјалната работа богато и разновидно практично искуство. Додека за социјалната работа е карактеристична поединечната перспектива, што има свој одраз во нејзиниот предмет, во социјалната педагогија релацијата помеѓу единката и општествениот контекст на нејзиниот живот е основна теоретска категорија, поради што ситуациите на единките и групите се дефинирани преку општите црти. 
Индивидуалната перспектива на социјалната работа ѝ дава на секоја единка посебен, уникатен карактер и специфичност. Како резултат на различниот пристап, во тие две дисциплини различна е поимовата апаратура, методолошките категории и методите на интервенција.

Кои аргументи треба да ги употребиме за да укажеме на евидентната разлика на социјална работа од другите научни области?

Како што знаеме, во социјалната работа се употребуваат три, веќе класични методи: индивидуална социјална работа(casework), групна социјална работа (groupwork) и социјална работа во локална заедница (community organization).

Според Б. Штур-Јаворска, дури до 60-тите години американските теоретичари не се обиделе да ги поврзат трите методи со заедничка теоретска платформа. Напротив, секоја метода била теоретски заснована на посебни научни дисциплини и различни теории(Sztur-JavorskaB, 2002; 76).

Во денешно време се забележува напредок на тој план, а концепциите кои ги поврзуваат методите во една целина може да се интерпретираат, според моето мислење, преку познатата теорија на Урие Бронфербренер (McMahon,1996:25). Како што знаеме, според неговата теорија, развојот на поединецот настапува под влијание на различни средински кругови. Теоријата на Бронфербренер помага да сфатиме зошто на различен начин се однесуваме и дејствуваме во различни социјални ситуации.

Прв вид на систем е микросистемот кој ги опфаќа субсистемите кои се базични, основни за секоја единка. На пример, домашната средина и искуствата на детето поврзани со релациите со мајката или таткото. Тие можат да бидат одлични или крајно несоодветни. Токму методите на социјалната работа се потребни во ризичната ситуација да се применува соодветна интервенција. Во овој случај со методот на индивидуална работа интервенираме во најблиското опкружување на единката.

Наредно ниво во концепцијата на Бронфербренер е мезосистемот кој опфаќа релации во кои учествува единката со различни формални и неформални групи. Искористувањето на 
Ревија за соиијална политика, год. 8, бр.11/2 Скопје, ноември 2015

групната социјална работа во ситуација кога единката има проблеми со функционирање во група е одличен методски предизвик.

Макросистемот, како последно ниво во Бронфербренеровата теорија, е збир на организации и идеологии присутни во секое општество. Секоја единка преку целиот свој живот воспоставува низа релации со елементите на макросистемот. Преку методот на социјална работа во локална заедница и́ помагаме на единката за подобро и поефикасно функционирање во заедницата. ${ }^{2}$

Се поставува прашањето зашто е толку проблематично да се изгради еден концизен теоретски систем кој се однесува на социјалната работа?

Пред сѐ, проблемите кои ги решава социјалната работа се комплексни, а истовремено неповторливи. Познато е дека сите социјални ризици не се лесни за надминување. Најчесто во нив истовремено се присутни различни негативни фактори.

Во едно проблематично семејство, на пример, секој член може да е носител на посебен ризик (алкохолизам, хронична болест, малолетничка деликвенција, пречки во развој), а освен тоа целото семејство како систем ги кумулира сите ризици кои се вкрстуваат меѓусебно. Комплексноста, посебноста и неможноста одреден ризик да се систематизира го детерминира карактерот на социјалната работа, која не може да се спореди со некоја друга дисциплина.

\section{2. Од грижа и помош кон државна и професионална заштита}

До крајот на 19. век социјалната работа постоела како општествена дејност, како израз на каритативни и милосрдни дела спрема сиромашни, болни, стари, деца без родители и родителска грижа и други ранливи категории на луѓе.

На професионална социјална работа, која се формира на преминот меѓу 19. и 20. век, и́ претходат низа облици на социјална

\footnotetext{
${ }^{2}$ Во концепцијата на авторот освен трите системи постојат и ексосистем и хроносистем. 
дејност организирана од соседски, семејни, верски, занаетски и други средини. Голем дел од тие активности имале и волонтерски карактер. Иако со потполна сигурност може да се каже дека социјалната работа е резултат на претходни доброволни искуства, волонтерските организации постојат и денес, и успешно се развиваат.

Оттука може да се констатира дека плуралниот пристап во решавање на социјалните проблеми, кој воедно е и принцип на модерната социјална заштита, бил отсекогаш присутен. После Втората светска војна комунистичката диктатура оставила малку место за приватни и невладини организации, сметајќи дека излегуваат надвор од идеолошко дозволените рамки .

Потребата од социјална работа е наметната од човековата природа. Имено, човекот ја формирал социјалната работа како дополнителен сегмент на својата целокупна природа, за да ја корегира својата несовршеност. Денес сме поврзани со низа новосоздадени институции, со чија помош ги решаваме класичните и новите потреби кои се производ на негативни последици од општествениот развој, популационите проблеми, нерамноправноста и девијациите.

Поради ова, социјалната работа го опфаќа она што класично го подразбираме под самата професија, односно помага на, и згрижува беспомошни, болни, стари лица во различни институции (непосредна заштита), но исто така во себе содржи педагошки, психолошки, правни, менаџерски и етички компоненти. Менаџирањето, особено се истакнува како новина во социјалната работа. Менаџерските вештини се присутни во управување на социјални институции, додека на Универзитетите постојат специјализирани студии по социјален менаџмент (воедно и во Македонија).

После Втората светска војна, благодарејќи на американскиот активист С. Алински настапува видлива промена во однос на корисниците на социјалните интервенции. Предмет на делување од страна на социјалните служби стануваат, не само социјални случаи, 
Ревија за соиијална политика, год. 8, бр.11/2 Скопје, ноември 2015

туку исто така и просечни граѓани. Активностите во местото на живеење се однесуваат на сите жители, и за оние кои се корисници на социјална помош и за оние коишто се на високо место во општествената стратификација. Значи, особено при реализација на методот социјална работа во локалната заедница, настапува пречекорување на тесната граница на социјалната работа сфатена како активност за луѓе кои самите не можат да ги решат своите проблеми. Локалното население со заеднички сили на луѓето, повисоко и пониско сместени во општествената хиерархија, ги развиваат и задоволуваат своите потреби (Доневска М., 2014:29).

Просечните граѓани го асоцираат поимот социјална работа со обезбедување на права и добивање услуги. Законот за социјална заштита подетално ги регулира задачите на државата од тој аспект.

Во Македонија од 1993 година беше воведено правото на социјална парична помош кое го користат голем број на домаќинства. Според информациите на Републичкиот завод на статистика во 2012 година социјална парична помош била дистрибуирана во 33717 домаќинства. Во претходните години бројките биле многу поголеми.

Социјалните служби развиваат различни услуги за граѓаните. Услугите се прилагодени на современиот начин на живеење. Користењето на услужни активности, посебно обезбедувани преку Центрите за социјална работа, се одвива на доброволна основа. Мајката или таткото на дете со воспитни проблеми соработува со социјалните служби, неколку пати доаѓа во социјалната институција, реализира договорени задачи. Тоа укажува дека способностите и вештините на вработените мора да бидат на високо ниво за да ги мотивираат луѓето за соработка. 
Мариа Доневска: Континуитет и промени во соиијалната работа...

\section{3. Од инспирација и имитација на општествените науки до сопствен методски опус}

Кога мислиме на специфичниот методски опус на социјалната работа треба да направиме разлика помеѓу поимите методика и методологија. Додека методологија се однесува на научниот метод, принципи и начини на истражување, методика се однесува на техничките аспекти на една дејност, конкретно на реализација на целите и задачите во практика. Во социјалните институции работата ја вршат сите профили вклучени во социјалната дејност. Тоа се социјални работници, психолози, педагози, правници и социолози.

Каде се забележува најголем прогрес? Да се обидеме да поставиме неколку тези.

- Процесот на социјалната работа се збогати со фазите на евалуација и најчесто во работа со поединец за фаза на контракт.

- Големо значење во социјалната работа, по примерот на психијатриските искуства, зазема супервизијата.

- Сè повеќе доминира релациски/стратешки модел, иако е присутен медицинскиот модел во работата.

- Класичните практични методи (работа со поединец, групна социјална работа, социјална работа во локална заедница) губат на значење. Социјалната работа се реализира во рамки на, т.н. збирна димензија.

- Практичните техники на работа се слични со активностите во образовните и воспитните институции, но некои од нив имаат посебно значење, на пример, програмирањето.

- Иако постојат бројни обиди за внесување ред во класификацијата на пристапите, и понатаму во овој домен постои хаос.

- Постои тенденција за обавување на работите на терен, преку домашни посети, средби со граѓани на локално ниво итн.

- Сепак, најголем прогрес може да се забележи во развојот на формите на социјалната работа. Со цела одговорност треба да се констатира дека, независно од сите аргументирани 
Ревија за соиијална политика, год. 8, бр.11/2 Скопје, ноември 2015

критики, во последните години социјалните дејности во нашата држава станаа сѐ потранспарентни во однос на граѓаните. Лицето кое се наоѓa во ризична ситуација има поголем избор да ги обезбеди своите потреби преку развиената мрежа на услуги во рамки на институционалните и вонинституционалните облици на социјална заштита. За разлика од претходно, Центрите за социјална работа се поврзани со различни видови на установи за социјална зштита, како што се дневните центри: за стари лица, за деца на улица/улични деца, за лица кои злоупотребуваат дроги и психотропни супстанции, за бездомници, за жртви на семејно насилство, за лица со телесна и ментална попреченост, како и мали групни домови, советувалишта за брак и семејство, терапевтски заедници и друго. Генерално, институционалните форми на помош се пренасочуваат кон вонинституционални облици (наместо домови за деца без родители и родителска грижа-згрижување во друго семјество).

Во обид да се пресретнат потребите на граѓаните во одреден број рурални и помали урбани општини отворени се подрачни канцеларии на Меѓуопштинските центри за социјална работа кои изведуваат одредени активности, помеѓу кои и реализација на правата за парични надоместоци. Некои од овие канцеларии работат постојано, со полно работно време, а некои делумно, еден до два дена неделно.

Во рамки на граѓанскиот сектор во Македонија, најмалку една треттина од вкупните активности имаат социјален карактер. Помеѓу позначајните ораганизации кои нудат помош и заштита на социјално раниливите категории на лица се: МЕЃАШИ, ХОПС, ЦИРА, ХЕРА. Овие организации имаат реализирано бројни проекти со кои влијаат на значајно намалување на социјалните ризици на граѓаните.

Сепак, во јавноста и понатаму постои потрага по нови решенија, настојувања за поефикасна работа и критички осврти. Најверојатно тоа се должи на природата на проблемите кои најчесто се егзистенцијални, значи најважни, а воедно и најнеопходни за санирање. 
Но истовремено со право се констатира дека бројот на стручниот кадар и соодветноста на стручните профили во Центрите за социјална работа, како основна јавна установа во системот на социјална заштита, не ги задоволува потребите на населението.

„Социјалната работа е ситуирана помеѓу светот на формалната институција и секојдневниот свет на човекот кој се нашол во сложена ситуација. Овие два света значајно се разликуваат... Социјалниот работник се наоѓа на граница помеѓу двата света... Тој мора постојано да решава која перспектива треба да ја претставува, дали треба да дејствува како претставник на институцијата или како човек кој сочувствува и разбира (Граносик М.,2008 :113-114)“.

- Паралелно со развојот на подрачјата во кои се движи човекот настанува и учеството на социјалните служби во нив. Традиционалните подрачја за работа на социјалните работници (социјална заштита, образование, здравство) се збогатени со спортски терени, просветно-воспитни институции, касарни, дискотеки и улица (интересна форма, како вид на секундарна превенција е патролната социјална работа - streetsocialwork).

Според нас приоритетно подрачје за социјалните работници е училиштето. Во образовните институции сметаме дека дел од проблемите не секогаш се од психо-педагошка природа туку и од социјална, па оттука и потребата за зајакнување на училишните стручни служби со вработување на социјални работници. Ова произлегува од две главни причини: составот на самите ученици, кои многу често се наоѓаат во проблематични социјални ситуации и неопходноста од воспоставање на мрежа на меѓусекторска соработка, со цел да се применуваат пристапи, методи и техники наменети на интервенции во превентивна и куративна смисла.

- Во социјалната работа денес се присутни нови содржини кои се сретнуваа и порано, иако не беа толку актуелни. Овде мислам на мултикултурализмот и родовата перспектива на социјалната работа. 
Ревија за соиијална политика, год. 8, бр.11/2 Скопје, ноември 2015

Демографските движења направија големи поместувања во составот на општествената структура на многу земји. Оттука, мултикултурализмот е модел кој меѓународната заедница го нуди како начин на решавање на проблемите кои денес се јавуваат во голем дел држави. Проблемите се рефлектираат врз теоријата и врз праксата на социјалната работа која во својата содржина го вградува концептот за човекови права, социјална правда и човекови разлики (Трбојевиќ С., 2014, 163-166).

Во социјалната работа, како професија и како општествена дејност со долга историја, отсекогаш постоела специфична родова хиерархија, а прашањето за родот било едно од главните прашања.

Независно од низата настојувања, присутни се разлики помеѓу мажите и жените во однос на нивниот социјален статус, како и во пристапот до различни добра. Поради тоа, жените и мажите се соочуваат со различни социјални ризици и различно се справуваат со нив. Оттука, во последно време доста е нагласена политиката на родова рамноправност, во чија реализција се вклучува и социјалната работа.

Искуствата на тој план датираат од почеток на оформување на професијата социјална работа, а главни претставници на феминистичката концепција на социјална работа се Џејн Адамс, Алис Саломон и Мери Ричмонд (Страмшак-Ѓуровска Б., 2014: 166-168).

- Во својата примарна концепција социјалната работа била насочена кон давање помош на лица, групи и заедници, но со текот на времето можеме да ги забележиме и другите нејзини функции. Класичната и основна помошна функција на социјалната работа со текот на времето се збогатува со поттикнување, развивање на самосвест и личните сили на странката (Дервишбеговиќ М., 1995:13).

Генерално, може да се каже дека акцентот на работата на социјалните служби се пренасочува од згрижувачки функции спрема странката, кон поттикнување на нејзиниот развој. 
Постојат многу облици на превентивни форми, посебно во локалната заедница, каде тие делумно се спроведувани од страна на социјалните установи и невладиниот сектор. Се организираат трибини, средби со граѓани и издавање на пропаганден и информативен материјал, се организираат групи на заемна помош (самохрани родители, згрижувачки семејства), се преземаат активности во однос на сексуални работнички, лица инфицирани со ХИВ, корисници на дроги, се спроведуваат проекти за здравствена едукација итн. Во сите превентивни програми се вклучуваат волонтери, а во последно време самите локални власти организираат многу социјални активности.

Во Македонија превентивната активност мора да се развива во поголема мера, посебно во често запоставените рурални средини.

Постојат дискусии околу воспитната функција на социјалната работа. Според мене, воспитанието е придружен фактор на сите активности кога работиме со случај група или локална заедница. Воспитната функција особено доаѓ до израз во процесите на ресоцијализација и рехабилитација.

\section{4. Значење на управувањето}

До пред неколку години во социјалните институции воопшто не се зборувало за социјален менаџмент, кој денес има значајна улога во нивното управување и во образованието на социјалните служби.

Во институците сѐ поголемо значение се придава на кариерниот развој на вработените, од една страна, и на односот социјален службеник - клиент, од друга. Односот на клиентот спрема социјалните институции е променлив. Корисникот сам ги избира услугите, а работата со него се одвива на доброволна основа. На тој факт посочува М. Payne, велејќи дека токму клиентот го внесува надворешниот свет во активностите на социјалните служби. Оттука, потребно е формулирање на улогата на клиентот и неговиот став спрема вработените (PayneM, 2002: 13). 
Ревија за соиијална политика, год. 8, бр.11/2 Скопје, ноември 2015

Значително долго време, посебно во клиничката социјална работа, е употребуван поимот клиент или пациент. Долги години интеракцијата на корисникот на услуги со социјалниот работник била пасивна. Лицето во ризична ситуација, под влијание на социјалниот службеник кој се однесувал како доктор (медицински модел), имало ограничена моќ. Промената се случила кога социјалните работници со бихејвиорална ореиентација во 1965 година воведуваат контракт, вид на договор помеѓу клиентот и социјалниот работник. Благодарение на договорот се изедначува позицијата на работа во заедничката интеракција. Но најтранспарентна, според D. Hove, еволуција на социјалната работа се случува преку промена на профилот „саsework” кон „casemanager” (HoveD.,1997).

Според различни истражувања односот на клиентот спрема социјалниот работник во секојдневната комуникација може да биде доминатен, воздржан, повлечен или експресивен. Во денешно време сѐ повеќе се настојува да ги подготвиме социјалните работници за дијагностоцирање и справување со различните стилови на однесување на клиентите, бидејќи секојдневната работа во социјалните институции е многу напорна и може негативно да влијае врз самиот социјален работник.

\section{5. рајноста на етичките принципи}

Спецификата на работата во социјалната дејност се состои во истовремена примена на различни професионални улоги. Тие постојано се менуваат на глобален план како резултат на општествените промени и во секој контакт со странката. Од една страна, забележителна е појава на сѐ поголема човекова слобода и зголемена можност за самореализација, од друга пак, како негативни придружнички на тие промени се јавуваат беспомошност, депресивност, неконвенцонални однесувања, различни патолошки појави, карактеристични не само за луѓе во ризична состојба. Современиот свет се наоѓa во хаос од норми и принципи, не е толку стабилен како што се очекуваше, нема јасно укажана перспектива за животот. 
Поради тоа луѓето кои работат во социјалните институции имаат многу сложена мисија. Согласно спецификата на промените, денешниот социјален работник е истовремено и консултант, предлагач на различни избори, водич, мобилизатор кој им помага на луѓето да се соочат со разновидни ризици. Не се важни само свесно користените форми, методи и техники, туку и однесувањето на социјалните работници, во однос на тоа какви луѓе се тие самите.

Оттука, социјалниот работник за да ја реализира својата мисија мора да е носител на знаења, вештини и компетенции, и тоа 3a:

- мериторни (знаења од одредена област),

- праксеолошки (вештини),

- комуникациски вештини,

- креативност,

- технички вештини,

- морални карактеристики.

Професијата социјален работник асоцира на хуманост, човечност, солидарност и социјална правда. Поради тоа личноста на социјалниот работник се идентификува со многу морални вредности. Истовремено тоа е професија која поради спецификите на секој случај, работата со ранливи категории на населението, постојано се наоѓa на крстопат во обавување на стручните задачи. Иако постојат принципи на социјална работа, не секогаш можеме доследно да ги почитуваме.

Основни дилеми во работата се:

- како да ја надминеме рутината и шемите во работењето и во секој момент да го почитуваме начелото „секој случај сам за себе?"

- како да се одбраниме од стигматизација?

- како, посебно во мали средини, да воспоставиме контакти со странки надвор од институцијата? 
Ревија за соиијална политика, год. 8, бр.11/2 Скопје, ноември 2015

- како да одлучиме и врз основа на што да примениме соодветен вид на третман со странка: третман наместо странка/ третман врз странка / или третман со странка?

- како брзо да процениме кои се слаби и јаки страни на странката?

- како да го разрешиме конфликтот помеѓу довербата на странка и нејзините негативни постапки?

- како да постапиме со доверливите информации добиени од странката, кога треба да ги споделиме со тимот?

- како да се ослободиме од презаситеност со негативни појави?

- како да ја регулираме својата емпатија?

- $\quad$ дали секогаш треба да постапуваме според стандардите и нормативите?

Вработените во Центрите за социјална работа нѐ информираат дека во последно време нема случаи со еден ризик. Секој случај претставува синдром на повеќе, зависни меѓу себе, вкрстени ризици. Многу често не се знае од каде треба да се започне интервенцијата.

Сите погоре посочени информации го отвораат прашањето за селекција на кандидатите кои сакаат да се бават со нашата професија. Во тој поглед постојат различни искуства во светот, но од друга страна испитувањата со студенти кои веќе студираат социјална работа во нашата земја покажуваат еден негативен тренд. За студентите како вредност најважна е моќта, хедонизмот, сообразноста и достигнувањето. Додека најмалку значајни се традицијата, самонасоката, универзализмот, безбедноста и добродушноста. Оваа хиерархија ги одразува вредностите независно од полот и националноста (Арнаудова С., Трајков И., 2014).

За среќа, споредувајќи различни дефиниции може да се заклучи дека вредностите се идеи, битија или поими кои постојат објективно, независно од тоа дали конкретни луѓе така ги третираат (SwidaH., $1979: 18$ ). 
Мариа Доневска: Континуитет и промени во соиијалната работа...

\section{6. Образование}

Најпред хронологија на најзначајните настани:

- Првите школи за социјална работа (со првичниот назив школи за филантропија) биле основани во Чикаго и Њујорк (1898 година);

- Во Европа првата школа била отворена во Амстердам;

- Bo 1928 година се формира IASSW (International Association of Schools of Social Work) - Меѓународно здружение на школи за социјална работа;

- Од седумдесеттите години на 20. век во Европа е присутна тенденцијата за образование на социјални работници во универзитетски рамки;

- Во Скопје, главниот град на Македонија, во 1957 година е формирана Средна школа за социјални работници, која во 1963 година прераснува во Виша школа;

- Во академската 1988/1989 година, во рамките на факултетско образование, започнува со студии првата генерација на студенти на Филозофскиот факултет;

- Согласно промените, поврзани со Европскиот кредит трансфер систем (ЕКТС), воведен во академската 2004/2005 година, во рамки на Институтот усогласени се сите нови студиски програми за додипломски студии (I циклус), постдипломски студии (II циклус) и докторски студии (III циклус);

- Од 2013 година, согласно актуелниот Закон за социјална заштита, за сите стручни работници вработени во Министерството за труд и социјална политика (МТСП), се задолжителни лиценци.

Забележуваме постепен развој на едукацијата на социјални работници, од апсолвенти на средни училишта, до доктори на наука. Тоа што посебно радува се регионалните програми за докторските студии (на пример, балканската мрежа). Во многу земји се отворааат нови студиски програми за социјална работа. Во рамки на студиите студентите можат да специјализират како социотерапевти, семејни 
Ревија за соиијална политика, год. 8, бр.11/2 Скопје, ноември 2015

терапевти, аниматори за развој на локалните заедници итн. Но истовремено во некои земји социјалната работа не се вбројува во списокот на научни дисциплини, иако во истите земји постојат студиски програми по социјална работа. Наставните програми на сите циклуси (додипломски, магистерски, докторски) постојано се менуваат согласно проширувањето на целите и задачите на социјалната работа и променливите човечки потреби.

За жал во програмите забележуваме намалување на класичните содржини во едукацијата на студенти. Наместо збогатена доза на методики, студентот добива воопштени информации за човекови права, демократија и одржлив развој. За студентите скоро и не постојат кабинети за практична настава. Тој факт е малку загрижувачки бидејќи студиите по социјална работа имаат апликативен карактер.

Вреди да размислиме, исто така, дали студиските програми се творба конструирана од наставниците ширум светот или влијание врз нивната концепција имаат монополски гиганти како Светска банка и средини од голем бизнис со неолиберална идеологија. Многу често, без посебно внимание, го копираме она што го има во западните земји, посебно примена на тестовите, што всушност наоѓ мала корист во студиските групи каде конечен е дијалогот помеѓу студентот и наставникот.

Најголемата замерка, според разговорите со нашите апсолвенти, се однесува на фактот дека на факултетот нема доволна подготовка за техники за справување со проблеми на работното место.

Во САД функционираат виртуелни програми A synchronous learning networks (ALNs) за лица кои студираат социјална работа како редовни и вонредни студенти. Во концепцијата се зема предвид оддалеченоста од образовните институции и времето. Освен тоа, има видео-конференции, интернет страници, разговори со гости во студио, размена на мејлови, линкови за стручни интернет страници. 
Во Австралија, поради големата оддалеченост од образовните центри, се оргнизираат видео-врски за групна терапија. Терапевтот има контакт со постојана група за интервенции, а и самите членови на група се гледаат на видеобим.

Најзначајно место сепак има практиката. За неа се потребни добро подготвени супервизори. На тој план потребно е да се работи.

\section{Наместо заклучок}

Во кратки црти, презентирано е она што во социјалната работа е присутно од почеток на нејзино званично постоење, како и она што е ново. Дали можеме да предвидиме што ќе случи понатаму?

Се надеваме дека во скоро време во сите земји социјалната работа ќе биде признаена како научна дисциплина.

За тоа потребна е и трансформација на самиот назив на науката која се бави со социјална работа. Во називите на општествените науки, а и во природните, во првиот дел има информација за главното поле на активност, додека во другиот суфикс - лого (наука), како на пример, психо/логија, социо/логија, антропо/логија. За социјалната работа нема ваков назив, иако во некои земји се предлага поимот социоагологија (наука за социјалната работа).

Според нашите предвидувања, установите за социјална работа ќe ce пренасочат во непосредното место на живеење на клиентите и ќe реализираат услуги во специјализирани локални сервиси за семејство, за стари лица, за деца со АДХД, за аутистични деца итн. Тој тренд е присутен од втората половина на 20. век, кога доминира преминот од централно уредуван модел кон пролокална ориентација. Во цела Европа преовладува мислењето дека локалниот модел дозволува подобар дијалог со корисниците на услуги.

Поради движењата на населението, предизвикано од различни фактори, во многу средини ќе се применува мултикултурна социјална работа. Некои автори сметаат дека клучот за работа во 
Ревија за соиијална политика, год. 8, бр.11/2 Скопје, ноември 2015

мултикултурна средина се наоѓа токму во способностите на социјалните служби.

Остварувањето на правата на граѓаните ќе го преземат локалните власти, преку формирање на еден заеднички пакет за секој граѓанин, составен од базични елементи во животот на секој човек (вработување, пензионирање, социјална помош, здравствена заштита).

Ќе се зголеми присуството на социјални работници на терен и во сите места каде функционира човекот. Bureau of Labor Statistics смета дека потребата за семејни терапевти ќе се зголеми до 2020 година за над 40\%. Потребни се луѓе со идеи, но пред сѐ со визии како подобро и поефикасно да му помогнат на клиентот.

Bureau of Labor Statistics се надева на развој на менаџерскиот кадар во областите кои имаат допирна точка со нашата професија. Тоа се меѓучовечки односи и планирање.

Во последно време сѐ повеќе се зборува за меѓународните димензии на социјалната работа и внесување на нови содржини во образованието на социјалните работници. Потребни се специјалисти кои се залагаат за глобални стратегии во борбата со негативните појави на меѓународен план.

Првите обиди за овој вид на образование ги забележуваме во програмите PHARE (Темпус, Еразмус) предложени од Европската заедница.

Во блиска иднина ќе се појават нови целни групи за превенција и куративна социјална работа, на пример, пропаднати штедачи. Денес, оваа група веќе се смета за маргинална и се наоѓa под заштита на социјалните центри во Виена.

Сепак во научната литература има и песимистички визии за иднина на социјалната работа.Тоа се должи на слаб развој на социјален капитал, неуспеси во фукционирање на граѓанското 
Мариа Доневска: Континуитет и промени во соиијалната работа...

општество, а пред сѐ ,што е доста карактеристично и за Македонија, недоволно истакнат етос на професијата социјален работник.

Заклучувајќи ги нашите анализи можеме да кажеме дека во социјалната работа, почнувајќи од нејзино формирање од пред 100 години, не е направен коперникански пресврт. Едноставно, општествените промени под влијание на процесот на глобализација, потребите на луѓето, ја збогатувале со нови пристапи, форми, а исто така и цели и задачи.

Може да се каже дека социјалната работа сѐ посмело си трасира место во семејството на општествените науки, но овој пат е изграден со бројни препреки. 


\section{Литература}

Арнаудова С.,Трајков И ,(2014), Values and Value Orientation Among Social Work Studens, Меѓуународна конференција на психолозии, УКИМ

Dervisbegovič M.,(1995) Socijalni rad, Sarajevo.

Доневска М., (2014) Теоретските основи на социјалната работа, II изданје, Филозофски факултет, Скопје

Граносик М., (2008) Професионализација на социјалните занаети, (Во ) Борнарова С (ред) Современи трендови во социјална заштита и социјачна работа, Филозофски факултет, Скопје

McMahon O M., (2012) The General Method of Social Work Practice Allyn and Bacon , 1996 (Wo:) Bornarova C, Socijalna rabota so semejstvio UKIM, Skopje

Payne M., (2002) Savremena teorija socijalnog rada, Filozofski Fakultet, Banja Luka

Szatur - Jaworska B., (1993) Teoria pracy socjalnej, Pedagogika spoleczna., Warszawa

Страмшак-Гјуровска Б., (2014) Социјалната работа и родот (Во) Доневска М., Теоретските основи на социјалната работа, Филозофски факултет, Скопје

Świda H., (1979) Młodzież i wartości, WSziP, Warszawa

Трбојевиќ С., (2014) Мултикултурализм (Во) Доневска М., Теоретските основи на социјалната работа, Филозофски факултет, Скопје

Frysztacki K., (2002) Wielowymiarowość pracy socjalnej, Akapit, Toruń

Xove D., (1997) Uvod u teoriju socijalnog rada, FPN, Beograd 